\title{
PReS-FINAL-2003: Remission and predictors of persistent disease activity at 30 years follow-up in a Norwegian cohort of juvenile idiopathic arthritis patients
}

\author{
AM Selvaag*, HA Aulie, V Lilleby, B Flatø \\ From 20th Pediatric Rheumatology European Society (PReS) Congress \\ Ljubljana, Slovenia. 25-29 September 2013
}

\section{Introduction}

Long-term studies of remission rates in juvenile idiopathic arthritis (JIA) are few and difficult to compare because of different definitions of remission.

\section{Objectives}

To assess disease activity in a previously studied cohort of JIA patients after 30 years of disease duration and reveal predictors of persistently active disease.

\section{Methods}

A total of 259 patients with JIA, first referred to our hospital from 1980 to1985, were reexamined clinically after median 15 years of disease duration, and by mailed questionnaires after median 23 years. These patients were invited to attend the present study. All patients were assessed by questionnaires, and those with signs of active disease after 15, 23 and/or 30 years were invited to a clinical reexamination. Inactive disease and remission were defined according to the recently developed preliminary criteria for clinical remission in JIA. Logistic regression analyses were used to assess predictors of active disease.

\section{Results}

One hundred and seventy-one patients (67\%) were included in the study. They were examined after a median of 30 (range 21-40) years of disease duration, median age was 39 (range 28-45) years and $74 \%$ were females. After 30 years, $59 \%$ of the patients were in clinical remission off medication, $7 \%$ were in remission on medication and 34\% had persistently active disease compared with $57 \%, 10 \%$, and 33\%, respectively, after 15 years.

Thirty-seven of 57 patients (65\%) with active disease at 15 years follow-up had active disease at 30 years follow-up, and 20 patients (35\%) went into remission on or off medication. Eighty-four of 97 patients (87\%) in remission off medication remained in this category from 15 to 30 years follow-up. Patients in remission on medication at 15 years ( $\mathrm{n}=17$ ) tended to flare or go into remission off medication. In total $121 / 171$ patients $(71 \%)$ had an unchanged category of disease activity from 15 to 30 years follow-up. Predictors of persistently active disease at 30 years followup were: being diagnosed with a JIA subgroup other than persistent oligoarticular and systemic JIA (OR 4.1, 95\%CI 1.5-11.5, $\mathrm{p}=0.006)$, being DR1 positive (OR 8.3, 95\% CI

Table 1

\begin{tabular}{lcccc}
\hline Disease activity at $\mathbf{1 5}$ years follow-up & Not in remission at $\mathbf{3 0}$ years & Remission on $\mathbf{m e d}$ at $\mathbf{3 0}$ years & Remission off $\mathbf{m e d}$ at $\mathbf{3 0}$ years \\
\hline Not in remission & $57(33 \%)$ & 37 & 9 & 11 \\
Remission on med. & $17(10 \%)$ & 9 & 2 & 6 \\
Remission off med. & $97(57 \%)$ & 12 & 1 & 84 \\
Total & $171(100 \%)$ & $58(34 \%)$ & $12(7 \%)$ & $101(59 \%)$ \\
\hline
\end{tabular}

med.: medication 
2.3-30.3, $\mathrm{p}=0.001$ ), a short duration of total time in remission (OR 9.0, 95\% CI 3.0-26.7, $\mathrm{p}<0.001$ ), and not being in remission at 15 years follow-up (OR 13.7, 95\%CI 4.9-38.4, $p<0.001)$, Nagelkerkes $R^{2}=65 \%$.

\section{Conclusion}

The overall remission rates were stable between 15 and 30 years, even though one third of the patients changed category of disease activity. JIA subgroup, genetic factors and time without remission were important predictors of longterm outcome.

\section{Disclosure of interest}

None declared.

\section{Acknowledgements}

Supported by the Norwegian Women's Public Health Association.

Published: 5 December 2013

doi:10.1186/1546-0096-11-S2-06

Cite this article as: Selvaag et al:: PReS-FINAL-2003: Remission and predictors of persistent disease activity at 30 years follow-up in a Norwegian cohort of juvenile idiopathic arthritis patients. Pediatric Rheumatology 2013 11(Suppl 2):O6.
Submit your next manuscript to BioMed Central and take full advantage of:

- Convenient online submission

- Thorough peer review

- No space constraints or color figure charges

- Immediate publication on acceptance

- Inclusion in PubMed, CAS, Scopus and Google Scholar

- Research which is freely available for redistribution

Submit your manuscript at www.biomedcentral.com/submit 